\title{
Faktor-Faktor Yang Mempengaruhi Minat Mahasiswa Pendidikan Profesi Akuntansi Memilih Profesi Sebagai Akuntan Publik
}

\author{
Pande Made Utariyani Dewi ${ }^{1}$ \\ Fakultas Ekonomi dan Bisnis \\ Universitas Udayana, Indonesia. \\ Email: uututariyd@gmail.com
}

\author{
Anak Agung Ngurah Agung \\ Kresnandra ${ }^{2}$ \\ Fakultas Ekonomi dan Bisnis \\ Universitas Udayana, Indonesia.
}

\begin{abstract}
ABSTRAK
Profesi dan karir sangat diperlukan untuk meningkatkan kelangsungan hidup seseorang. Penelitian ini bertujuan untuk menguji secara empiris pengaruh penghargaan finansial, pelatihan professional dan lingkungan kerja pada minat mahasiswa Pendidikan Profesi Akuntansi memilih profesi sebagai akuntan publik. Sampel diperoleh dengan metode nonprobability sampling dengan teknik sampling jenuh. Responden adalah mahasiswa Pendidikan Profesi Akuntansi Universitas Udayana angkatan 2017 dengan jumlah 30 mahasiswa. Teknik analisis data yang digunakan adalah analisis regresi linear berganda. Berdasarkan hasil analisis menunjukan bahwa penghargaan finansial berpengaruh positif pada minat mahasiswa pendidikan profesi akuntansi memilih profesi sebagai akuntan publik. Pelatihan profesional berpengaruh positif pada minat mahasiswa pendidikan profesi akuntansi memilih profesi sebagai akuntan publik. Lingkungan kerja berpengaruh positif pada minat mahasiswa pendidikan profesi akuntansi memilih profesi sebagai akuntan publik.
\end{abstract}

Kata Kunci : Penghargaan Finansial; Pelatihan Professional; Lingkungan Kerja.

\section{Factors That Affect Interest in Accounting Professional Education Students Choose the Profession as a Public Accountant}

\begin{abstract}
Professions and careers are needed to improve one's survival. This study aims to empirically examine the effect of financial awards, professional training and work environment on the interest of Accounting Professional Education students to choose a profession as public accountant. Samples were obtained by nonprobability sampling method with saturated sampling techniques. Respondents were students of Accounting Professional Education at Udayana University in 2017 with 30 students. The data analysis technique used is multiple linear regression analysis. Based on the results of the analysis show that financial rewards have a positive effect on the interest of accounting profession education students to choose a profession as a public accountant. Professional training has a positive effect on the interest of accounting profession education students in choosing a profession as a public accountant. The work environment has a positive effect on the interest of accounting profession education students in choosing a profession as a public accountant.
\end{abstract}

Keywords: Financial Awards; Professional Training; Work Environment.

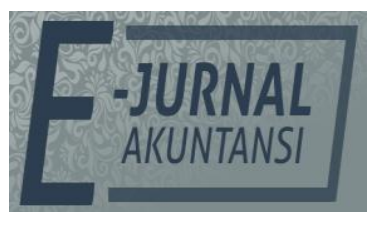

E-JA

e-Jurnal Akuntansi e-ISSN 2302-8556

Vol.298 No. 1

Denpasar, Oktober

2019

Hal. 173-187

Artikel masuk: 17 Januari 2019

Tanggal diterima: 05 September 2019 


\section{PENDAHULUAN}

Profesi dan karir sangat diperlukan untuk meningkatkan kelangsungan hidup seseorang. Karir adalah sebuah proses seumur hidup yang telah direncanakan dari tahap awal, sedangkan pemilihan karir memang harus dipertimbangkan dan direncanakan sedini mungkin karena keterbatasan yang dimiliki seseorang. Dalam arti sebagai seorang pelajar dalam mengambil keputusan menyangkut masa depan haruslah memikirkan yang terbaik untuk dirinya sendiri dan mampu bermanfaat bagi orang lain.

Karir dalam bidang akuntansi cukup luas antara lain akuntan publik, akuntan perusahaan, akuntan pendidik dan akuntan pemerintah (Chan, 2012). Adapun keinginan setiap mahasiswa akuntansi pada umumnya adalah untuk menjadi seorang yang profesional dalam bidang akuntansi. Untuk menjadi profesional dalam bidang akuntansi dapat dilakukan salah satunya yaitu dengan bekerja sebagai akuntan publik. Seorang mahasiswa dalam merencanakan karirnya tentu mempunyai pertimbangan atau faktor -faktor yang mempengaruhi dalam menentukan profesi yang akan dipilih. Hal apa yang menjadi latar belakang pemilihan profesi tersebut dan apa yang diharapkan mahasiswa dari pilihannya tersebut merupakan pertanyaan penting dalam pemilihan profesi.

Karir merupakan suatu akumulasi pengetahuan yang tertanam pada skill, expertise, dan jaringan hubungan kerja yang diperoleh melalui serangkaian perkembangan pengalaman kerja yang jauh lebih luas (Bird, 1994 dalam Deasy, 2000). Sebaliknya, (Greenberg dan Baron, 2000: 215) menyatakan bahwa karir tersebut meliputi prosedur pengalaman pekerjaan seseorang selama jangka waktu tertentu.

Bagi mahasiswa pendidikan profesi akuntansi, menentukan sebuah karir adalah sebuah tahap awal dari pembentukan karir tersebut. Setelah berhasil menyelesaikan di jenjang perkuliahan, pilihan karir bagi lulusan akuntansi tidak tertutup pada satu karir akuntansi saja karena banyaknya faktor yang melatarbelakangi pemilihan karir tersebut. Terdapat beberapa jenis karir yang dapat dipilih oleh mahasiswa akuntansi yang telah menjadi sarjana, yaitu sebagai akuntan publik, akuntan pendidik, akuntan pemerintah dan akuntan perusahaan.

Secara umum (Suyono, 2014) menyatakan bahwa, mahasiswa akuntansi yang telah menyelesaikan jenjang S1-nya memiliki beberapa pilihan dalam menentukan karir selanjutnya. Pertama, mereka (lulusan sarjana S1) dapat langsung bekerja sebagai karyawan di sebuah perusahaan ataupun instansi pemerintah. Kedua, mereka dapat melanjutkan pendidikannya ke jenjang selanjutnya yaitu S2 atau alternatif ketiga yaitu menjadi seorang akuntan publik. Bagi mereka yang memilih menjadi seorang akuntan publik, mereka harus melalui pendidikan Profesi Akuntan dan meraih gelar akuntan, selanjutnya mereka dapat memilih karir sebagai akuntan, baik sebagai akuntan publik, akuntan manajemen, akuntan pemerintah maupun akuntan pendidik. Setiap sarjana akuntansi bebas untuk memilih karir yang akan dijalaninya sesuai dengan keinginan dan harapannya masing-masing.

Berlakunya Asean Economic Community (AEC) yang memberikan peluang dan tantangan kepada mahasiswa sekaligus akuntan untuk mempersiapkan 
profesionalitas. Mahasiswa jurusan akuntansi dapat meningkatkan profesionalitas melalui Pendidikan Profesi Akuntansi (PPAk) untuk memperoleh gelar akuntan profesional Internasional Chartered Accountant (Hassan, 2012).

Penelitian yang dilakukan oleh (Sembiring, 2009), menunjukan bahwa hasil penelitian membuktikan penghargaan finansial, pelatihan profesional, pengakuan profesional, nilai-nilai sosial, lingkungan kerja, pertimbangan pasar kerja dan personalitas berpengaruh terhadap minat menjadi akuntan publik. Secara parsial variabel pengakuan profesional berpengaruh secara signifikan terhadap pemilihan karir menjadi akuntan publik. Sedangkan penghargaan finasial, pelatihan profesional, nilai-nilai sosial, lingkungan kerja, pertimbangan pasar kerja dan personalitas tidak berpengaruh secara signifikan terhadap pemilihan karir menjadi akuntan publik.

Mahasiswa banyak merencanakan berdasarkan apa yang mereka harapkan atau inginkan dalam profesi yang akan mereka tekuni, perencanaan karirnya seperti halnya mahasiswa akuntansi memilih karir sebagai akuntan publik. Sebelum mereka memilih karir tersebut mereka telah mempertimbangkan dan memilih seperti apakah pekerjaan dan tanggung jawab yang akan mereka hadapi saat mereka menekuni profesi tersebut. Pemilihan karir di dunia kerja terdapat beberapa profesi yang dipilih oleh sarjana akuntansi misalnya seperti profesi akuntan publik.

Profesi akuntan publik merupakan pihak yang menjadi mediator hubungan antara pihak manajemen dan pemilik manajemen yang mengelola suatu unit usaha (Lara, 2011) sedangkan (Victor, 2007) mengatakan bahwa ratarata mahasiswa memilih jurusan akuntansi, didorong oleh faktor keinginan mereka sendiri untuk menjadi profesional di bidang akuntansi. Profesi akuntan publik merupakan profesi yang dipandang menjanjikan prospek yang cerah karena profesi ini dipercaya dapat memberikan tantangan intelektual dan pengalaman belajar yang tidak ternilai (Wheeler, 1983). Banyak ditemukan ketidaksesuaian ekspektasi mahasiswa akuntansi terhadap tanggung jawab dan pekerjaan sebagai akuntan publik (Carl and Jhon, 1996). Hal tersebut menandakan bahwa mahasiswa belum memahami secara mendalam mengenai dunia kerja yang akan mereka jumpai pada nantinya ketika mereka menekuni suatu profesi dalam hal ini yaitu profesi akuntan publik.

Mahasiswa akuntansi memiliki berbagai macam persepsi untuk memilih karir yang akan dijalaninya yang terdiri dari lingkungan kerja, nilai-nilai sosial, pertimbangan pasar kerja, dan personalitas. Lingkungan kerja, dipertimbangkan dalam pemilihan profesi mahasiswa terutama pada sifat pekerjaan rutin dan pekerjaan cepat diselesaikan (Wijayanti, 2001). Mahasiswa menganggap profesi akuntan perusahaan akan menghadapi pekerjaan yang rutin dan dapat diselesaikan di belakang meja, sedangkan profesi akuntan publik akan menghadapi banyak tekanan dan tingkat kompetisi yang tinggi (Aprilyan, 2011).

Penghargaan finansial, dipertimbangkan dalam pemilihan profesi mahasiswa karena penghargaan finansial merupakan salah satu alat guna menjalani hidup seseorang. Penghargaan finansial juga dapat menjadi daya tarik tersendiri bagi para pelakunya. Profesi sebagai akuntan publik memiliki lingkungan pekerjaan yang menantang sehingga penghargaan finansial yang didapatkan akan sesuai dengan yang dikerjakan. Seseorang yang memilih 
profesi sebagai akuntan publik dapat melakukan tantangan yang diinginkan sesuai dengan penghargaan finansial yang didapat. Penghargaan finansial juga menjadi pertimbangan mahasiswa profesi akuntansi demi kesenjangan hidup berkeluarga pada nantinya. Sehingga diharapkan mahasiswa memikirkan profesi bukan hanya sebatas sampai lulus profesi akuntansi tetapi mempertimbangkannya sampai saat memiliki kehidupan yang baru.

Pelatihan profesional, dipertimbangkan dalam pemilihan profesi mahasiswa terutama pada kemahiran individu, meningkatkan daya kemampuan individu dan juga belajar agar lebih maksimal di bidang tersebut. Pelatihan profesional didapati ketika seseorang memilih profesi di bidang yang melaksanakan pelatihan professional di perusahaannya. Pelatihan professional menjadi salah satu daya tarik seseorang memilih karir, karena selain dapat meningkatkan kualitas kemampuan diri, pelatihan professional juga dapat membentuk suatu karakter pribadi seseorang kearah yang lebih baik lagi contohnya seperti kedisiplinan dan kerajinan.

Lingkungan kerja menjadi salah satu pertimbangan yang akan berpengaruh pada pemilihan karir seseorang dikarenakan lingkungan kerja tersebut akan membawa dampak terhadap kehidupan individu seseorang. Contohnya, seorang akuntan publik memilih lingkungan yang menantang oleh karena itu seseorang akan tertantang untuk menyelesaikan target pekerjaan. Sehingga lingkungan pekerjaan tersebut akan membawa dampak pada kehidupan seseorang yaitu menjadi lebih disiplin dan menghargai waktu.

Teori motivasi, teori harapan dan teori kepuasan merupakan landasan teori yang digunakan dalam penelitian ini. Motivasi merupakan uraian kekuatan-kekuatan yang terdapat pada diri seseorang yang mampu mengarahkan perilaku orang atau karyawan tersebut (Gibson dalam Lestari, 2016). Teori pengharapan menjelaskan kecenderungan untuk bertindak dengan suatu cara tertentu tergantung pada kekuatan atau pengharapan bahwa tindakan tersebut akan diikuti oleh suatu hal tertentu bagi setiap individu (Robbins, 2011). Teori kepuasan berakitan dengan kebutuhan apa yang mampu meningkatkan dan mendorong semangat dan keinginan seseorang dalam bekerja.

Hasil penelitian yang dilakukan oleh (Suyono, 2014) mendapatkan hasil bahwa variabel penghargaan finansial secara parsial berpengaruh signifikan terhadap pemilihan karir sebagai akuntan publik oleh mahasiswa akuntansi. Hasil penelitian ini sejalan dengan penelitian yang dilakukan oleh (Wijayanti, 2001) dan (Aprilyan, 2011) yang menunjukkan bahwa penghargaan finansial merupakan variabel yang di pertimbangkan dan berpengaruh dalam pemilihan karir akuntan publik.

Mahasiswa akuntansi yang memilih karir menjadi akuntan publik lebih mengharapkan penghargaan finansial/gaji jangka panjang, gaji awal yang lebih tinggi dan kenaikan penghargaan finansial yang cepat. Berkarir di Kantor Akuntan Publik dapat menghasilkan pendapatan yang tinggi atau besar dan bervariasi dibandingkan dengan pendapatan yang diperoleh dari karir yang lain, karena semakin besar perusahaan atau klien yang menggunakan jasa akuntan publik, pendapatan yang diterima akan semakin tinggi.

$\mathrm{H}_{1}$ : Semakin tinggi penghargaan finansial yang diharapkan, semakin tinggi minat mahasiswa PPAk memilih profesi sebagai akuntan publik. 
Hasil penelitian (Aprilyan, 2011), yang mana pelatihan profesional dipertimbangkan oleh mahasiswa yang memilih profesi akuntan publik. Menurut hasil penelitian (Stolle, 1976) menunjukkan bahwa, mahasiswa tingkat IV beranggapan akuntan publik lebih memerlukan pelatihan kerja dan lingkungan kerjanya lebih variatif, karena lingkungan kerja yang lebih variatif ini maka perlu pelatihan kerja yang lebih banyak daripada karir sebagai akuntan perusahaan. Mahasiswa akuntansi yang memilih karir menjadi akuntan publik menganggap perlu untuk melakukan pelatihan kerja karena untuk menjadi seorang akuntan publik yang dapat melaksanakan pekerjaan audit dengan baik, tidak cukup hanya dengan bekal pendidikan formal semata tetapi juga harus ditunjang oleh pengalaman praktek di lapangan dengan jam kerja yang memadai.

Wildiana (2014) dapat disimpulkan bahwa faktor pelatihan profesional berpengaruh positif dan signifikan terhadap pemilihan karir mahasiswa S1 akuntansi sebagai akuntan publik. Hasil penelitian ini sejalan dengan penelitian (Alhadar, 2013) dan (Nugroho, 2014). Mahasiswa S1 akuntansi yang memilih karir menjadi akuntan publik menganggap perlu untuk melakukan pelatihan kerja karena untuk menjadi seorang akuntan publik yang dapat melaksanakan pekerjaan audit dengan baik, tidak cukup hanya dengan bekal pendidikan formal semata tetapi juga harus ditunjang oleh pengalaman praktek di lapangan dengan jam kerja yang memadai (Stolle, 1976) dalam (Alhadar, 2013).

$\mathrm{H}_{2}$ : Semakin sering pelatihan professional diikuti, semakin tinggi minat mahasiswa PPAk memilih profesi sebagai akuntan publik.

Hasil penelitian ini menjelaskan bahwa secara parsial, lingkungan kerja tidak berpengaruh secara signifikan terhadap pemilihan karir menjadi akuntan publik oleh mahasiswa akuntansi. Mahasiswa akuntansi yang memilih karir menjadi akuntan publik menganggap segala sesuatu yang akan terjadi didalam lingkungan kerja akuntan publik pada saat ia bekerja nanti merupakan suatu pengorbanan yang harus dihadapi dan bagi mahasiswa akuntansi tersebut penghargaan atau kepuasan yang akan ia dapatkan nanti lebih besar daripada pengorbanan yang ia hadapi. Hasil penelitian ini sejalan dengan penilitian (Aprilyan, 2011), namun berbeda dengan penelitian yang dilakukan oleh (Wijayanti, 2001) yang menunjukkan bahwa lingkungan kerja, dipertimbangkan dalam pemilihan profesi mahasiswa terutama pada sifat pekerjaan rutin dan pekerjaan cepat diselesaikan. Menurut hasil penelitian (Hadi, 2012) Lingkungan kerja berpengaruh positif dan signifikan terhadap pemilihan karir sebagai akuntan profesional.

Hasil ini sejalan dengan temuan (Yudhantoko, 2013) dan (Dwinanda, 2014) yang mana secara parsial lingkungan kerja berpengaruh terhadap pemilihan karir mahasiswa. Hasil ini membuktikan bahwa lingkungan kerja menjadi pilihan yang masih dipertimbangakan oleh mahasiswa S1 akuntansi, dengan demikian hasil ini juga seakan memberi kesan bahwa karir sebagai akuntan professional merupakan karir yang tidak membosankan walaupun adanya kompetisi dan tekanan dalam bekerja yang tercermin dari jawaban responden atas angket yang peneliti sebar dan didukung dengan tingkat signifikan yang sangat tinggi. 
Lingkungan kerja tidak berpengaruh secara signifikan terhadap pemilihan karir mahasiswa S1 akuntansi sebagai akuntan publik. Hasil penelitian ini sejalan dengan penilitian (Chairunisa, 2014) dan (Alhadar, 2013) yang menunjukkan bahwa lingkungan kerja tidak berpengaruh signifikan terhadap dalam pemilihan karir mahasiswa S1 akuntansi sebagai akuntan publik, namun berbeda dengan hasil penelitian (Astuti, 2014) yang menyatakan bahwa lingkungan kerja mempunyai pengaruh positif dan signifikan terhadap pemilihan karir mahasiswa S1 akuntansi sebagai akuntan publik. Mahasiswa S1 akuntansi kemungkinan akan memilih karir menjadi akuntan bidang lain selain akuntan publik dengan pertimbangan bahwa mereka lebih menyukai pekerjaan yang rutin dibandingkan pekerjaan yang tidak rutin.

$\mathrm{H}_{3}$ : Semakin kondusif lingkungan kerja yang didapatkan, semakin tinggi minat mahasiswa PPAk memilih profesi sebagai akuntan publik.

\section{METODE PENELITIAN}

Penelitian ini dilakukan untuk mengkaji pengaruh penghargaan finansial, pelatihan profesional, dan lingkungan kerja pada minat mahasiswa PPAk memilih karir sebagai akuntan publik. Lokasi penelitin ini adalah di Universitas Udayana yaitu program PPAk yang berlokasi di Jl. PB Sudirman, Denpasar. Lokasi tersebut dipilih sebagai lokasi penelitian karena pengetahuan mahasiswa PPAk yang jauh lebih banyak mengenai profesi akuntansi dari pada mahasiswa S1 dengan bergelar Sarjana Ekonomi. Oleh karena itu penulis ingin melakukan penelitian mengenai profesi yang akan dipilih oleh mahasiswa profesi PPAk dengan indikator pemilihan profesinya yaitu faktor penghargaan finansial, pelatihan profesional dan lingkungan kerja.

Variabel bebas dalam penelitian ini adalah penghargaan finansial $\left(\mathrm{X}_{1}\right)$, pelatihan profesional $\left(X_{2}\right)$ dan lingkungan kerja $\left(X_{3}\right)$. Penghargaan $\left(X_{1}\right)$ adalah hasil yang diperoleh sebagai kontrak prestasi yang telah diyakini secara mendasar bagi sebagian perusahaan sebagai daya tarik utama untuk memberikan keputusan kepada karyawan. Menambahkan penghargaan finansial diuji dengan tiga butir pernyataan yaitu gaji awal yang tinggi, potensi kenaikan gaji dan tersedianya dana pensiun.

Pelatihan profesional $\left(\mathrm{X}_{2}\right)$ meliputi hal-hal yang berhubungan dengan peningkatan keahlian. Pelatihan profesional diuji dengan empat pernyataan mengenai pelatihan sebelum mulai bekerja, pelatihan profesional, pelatihan kerja rutin dan pengalaman kerja. Pelatihan dan pengakuan profesional termasuk faktor penghargaan non finansial. Perbedaan tersebut akan dilihat karena kemungkinan antara satu jenis profesi dengan jenis profesi yang lain memberikan penghargaan non finansial ini dengan cara yang berbeda. Lingkungan kerja $\left(\mathrm{X}_{3}\right)$ merupakan lingkungan dimana seseorang bekerja yang dapat merubah mindset seseorang ketika bekerja dan menjalakan tugasnya, serta berkaitan dengan metode kerja serta pengaturan kerja pada perseorangan maupun kelompok dalam lingkungan tersebut. Indikator lingkungan kerja adalah suasana kerja, hubungan dengan rekan kerja, dan tersedianya fasilitas kerja.

Variabel terikat dalam penelitian ini adalah profesi akuntan publik $(\mathrm{Y})$. Profesi sebagai Akuntan Publik (Y) atau Akuntan profesional merupakan suatau 
jenjang karir yang menjual jasanya kepada masyarakat, terutama bidang pemeriksaan terhadap laporan keuangan yang dibuat oleh kliennya. Dalam hal ini seorang akuntan dapat melalui jenjang karir di dalam perusahaan. Pemeriksaan laporan keuangan tersebut terutama ditujukan untuk memenuhi kebutuhan para kreditor, investor, calon kreditor, calon investor, dan instansi pemerintah (terutama instansi pajak).

Berdasarkan lokasi penelitian yang bertempat di Fakultas Ekonomi dan Bisnis Universitas Udayana, maka dapat dilihat besarnya populasi mahasiswa pendidikan profesi akuntansi yang berjumlah 30 orang mahasiswa. Metode penentuan sampel dalam penelitian ini adalah dengan menggunakan metode sampling jenuh yang merupakan teknik penentuan sampel yang dimana seluruh anggota populasi digunakan sebagai sampel. Sampel dalam penelitian ini yaitu mahasiswa PPAk Universitas Udayana berjumlah 30 orang.

Teknik analisis yang digunakan dalam penelitian ini adalah analisis regresi berganda, yang dilakukan untuk mengetahui hubungan antar lebih dari dua variabel, yaitu satu variabel sebagai variabel dependen dan beberapa variabel lain sebagai variabel independen. Pengujian hipotesis dengan analisis regresi linear berganda pada penelitian ini diformulasikan sebagai berikut:

$Y=\alpha+\beta 1 X 1+\beta 2 X 2+\beta 3 X 3+e$.

Keterangan:

$\mathrm{Y} \quad=$ Pemilihan karir sebagai akuntan publik

a $\quad=$ Konstanta (nilai $\mathrm{Y}$ apabila $\mathrm{X}=0$ )

$\beta=$ Koefisien regresi dari $X$

$\mathrm{X} 1=$ Penghargaan finansial

$\mathrm{X} 2=$ Pelatihan profesional

X3 = Lingkungan kerja

e $\quad=$ Kesalahan residual (error)

Ketepatan dari fungsi regresi sampel dalam menaksir nilai actual diukur dari goodness of fit-nya (Ghozali, 2011:97). Secara statistik, hal tersebut dapat dilihat dari nilai koefisien determinasi $\left(R^{2}\right)$, nilai statistik $F$ (uji kelayakan model), dan nilai statistik $\mathrm{t}$ (uji signifikansi parameter individual).

\section{HASIL DAN PEMBAHASAN}

Penelitian ini dilakukan untuk menguji pengaruh penghargaan finansial, pelatihan profesional, dan lingkungan kerja pada minat mahasiswa PPAk memilih karir sebagai akuntan publik. Data dikumpulkan dengan menyebarkan kuesioner ke 30 mahasiswa PPAk Universitas Udayana. Karakteristik responden penelitian ini dapat dilihat berdasarkan jenis kelamin, umur dan status pekerjaan. Berdasarkan hasil penelitian yang dilaksanakan dapat dijelaskan gambaran mengenai responden berdasarkan jenis kelamin. Karakteristik responden dapat dilihat melalui Tabel 1.

Tabel 1. Jumlah Responden Berdasarkan Jenis Kelamin

\begin{tabular}{lcc}
\hline \multicolumn{1}{c}{ Data Gender } & Jumlah & Presentase (\%) \\
\hline Laki & 17 & 57 \\
Perempuan & 13 & 43 \\
Total & 30 & 100 \\
\hline
\end{tabular}

Sumber: Data Penelitian, 2018 
Data Karakteristik responden meliputi gender yang di uraikan bahwa gender digunakan untuk mengetahui proporsi gender responden. Responden yang memiliki gender laki-laki berjumlah 17 orang ( 57 persen) dan responden yang memiliki gender perempuan berjumlah 13 orang (43 persen).

Berdasarkan hasil penelitian yang dilaksanakan dapat dijelaskan gambaran mengenai responden berdasarkan umur. Karakteristik responden dapat dilihat melalui Tabel 2.

Tabel 2. Jumlah Responden Berdasarkan Umur

\begin{tabular}{ccc}
\hline Umur (Tahun) & F (Frekuensi) & Jumlah Responden \% \\
\hline 22 & 3 & 10 \\
23 & 18 & 60 \\
24 & 3 & 10 \\
35 & 6 & 20 \\
Total & 30 & 100 \\
\hline
\end{tabular}

Sumber: Data Penelitian, 2018

Data karakteristik responden meliputi gender yang di uraikan bahwa umur digunakan sebagai pembanding minat antar responden. Responden yang berusia 22 Tahun berjumlah 3 orang (10 persen), berusia 23 Tahun berjumlah 18 orang (60 persen), berusia 24 Tahun berjumlah 3 orang (10 persen), dan berusia 35 Tahun berjumlah 6 orang (20 persen).

Berdasarkan hasil penelitian yang dilaksanakan dapat dijelaskan gambaran mengenai responden berdasarkan status pekerjaannya. Karakteristik responden dapat dilihat melalui Tabel 3.

Tabel 3. Jumlah Responden Berdasarkan Status Pekerjaan

\begin{tabular}{lcc}
\multicolumn{1}{c}{ Status Pekerjaan } & F (Frekuensi) & Jumlah Responden \% \\
\hline Bekerja & 29 & 99 \\
Belum Bekerja & 1 & 1 \\
Total & 30 & 100 \\
\hline
\end{tabular}

Sumber: Data Penelitian, 2018

Data karakteristik responden meliputi status pekerjaan yang di uraikan bahwa status pekerjaan digunakan sebagai pembanding minat antar responden. Responden yang bekerja berjumlah 29 orang (99 persen), yang belum bekerja berjumlah 1 orang (1 persen).

Sebelum dilakukan pengujian lebih lanjut maka perlu adanya uji instrument yang meliputi uji validitas dan uji reliabilitas. Pengujian validitas setiap butir digunakan analisis item, yang mengkorelasikan skor setiap butir dengan skor total yang merupakan jumlah setiap skor butir. Menurut (Sugiyono, 2012:109) bahwa suatu instrument dikatakan valid apabila koefisien korelasi antar butir pertanyaan $>0,361$. Berdasarkan Tabel 4 semua variabel memiliki nilai koefisien korelasi berada di atas 0,361 , sehingga layak dijadikan instrumen penelitian. 
Tabel 4. Hasil Uji Validitas

\begin{tabular}{|c|c|c|c|c|c|}
\hline \multirow{2}{*}{ No. } & \multirow{2}{*}{ Variabel } & \multirow{2}{*}{ Item } & \multicolumn{2}{|c|}{ Validitas } & \multirow{2}{*}{ Keterangan } \\
\hline & & & KoefisienKorelasi & Standar & \\
\hline \multirow[t]{3}{*}{1} & Penghargaan Finansial & $\mathrm{X}_{1.1}$ & 0,827 & 0,361 & Valid \\
\hline & $\left(X_{1}\right)$ & $\mathrm{X}_{1.2}$ & 0,817 & 0,361 & Valid \\
\hline & & $\mathrm{X}_{1.3}$ & 0,827 & 0,361 & Valid \\
\hline \multirow[t]{4}{*}{2} & Pelatihan Profesional & $\mathrm{X}_{2.1}$ & 0,743 & 0,361 & Valid \\
\hline & $\left(X_{2}\right)$ & $X_{2.2}$ & 0,853 & 0,361 & Valid \\
\hline & & $X_{2.3}$ & 0,816 & 0,361 & Valid \\
\hline & & $\mathrm{X}_{2.4}$ & 0,786 & 0,361 & Valid \\
\hline \multirow[t]{3}{*}{3} & LingkunganKerja $\left(\mathrm{X}_{3}\right)$ & $X_{3.1}$ & 0,879 & 0,361 & Valid \\
\hline & & $X_{3.2}$ & 0,844 & 0,361 & Valid \\
\hline & & $\mathrm{X}_{3.3}$ & 0,891 & 0,361 & Valid \\
\hline \multirow[t]{8}{*}{4} & Minat Mahasiswa PPAk & $\mathrm{Y}_{1}$ & 0,472 & 0,361 & Valid \\
\hline & Memilih Karir Sebagai & $\mathrm{Y}_{2}$ & 0,552 & 0,361 & Valid \\
\hline & Akuntan Publik (Y) & $\mathrm{Y}_{3}$ & 0,498 & 0,361 & Valid \\
\hline & & $\mathrm{Y}_{4}$ & 0,613 & 0,361 & Valid \\
\hline & & $\mathrm{Y}_{5}$ & 0,714 & 0,361 & Valid \\
\hline & & $\mathrm{Y}_{6}$ & 0,698 & 0,361 & Valid \\
\hline & & $\mathrm{Y}_{7}$ & 0,550 & 0,361 & Valid \\
\hline & & $\mathrm{Y}_{8}$ & 0,585 & 0,361 & Valid \\
\hline
\end{tabular}

Sumber: Data Penelitian, 2018

Reliabilitas adalah derajat ketepatan, ketelitian atau keakuratan yang ditunjukkan oleh instrument pengukuran dimana pengujiannya dapat dilakukan secara internal, yaitu pengujian dengan menganalisis konsistensi butir-butir yang ada. Nilai suatu instrument dikatakan reliabel bila nilai Cronbach's Alpha $\geq 0,60$ (Umar, 2008:207). Hasil uji reliabilitas ditunjukkan pada Tabel 5 sebagai berikut.

\section{Tabel 5. Hasil Uji Reliabilitas}

\begin{tabular}{llcccc}
\hline \multirow{2}{*}{ No. } & \multicolumn{1}{c}{ Variabel } & Item & \multicolumn{2}{c}{ Reliabilitas } \\
& & Alpha & Standar & Keterangan \\
\hline 1 & Penghasilan finansial & X1 & 0,840 & 0,6 & Reliabel \\
2 & Pelatihan professional & X2 & 0,815 & 0,6 & Reliabel \\
3 & Lingkungan kerja & X3 & 0,853 & 0,6 & Reliabel \\
4 & Minat mahasiswa PPAk & Y & 0,736 & 0,6 & Reliabel \\
& memilih karir sebagai & & & & \\
& akuntan public & & & &
\end{tabular}

Sumber: Data Penelitian, 2018

Berdasarkan Tabel 5 semua variabel memiliki nilai koefisien Alpha Cronbach berada di atas 0,6 sehingga semua instrumen tersebut adalah reliabel, sehingga layak dijadikan instrumen penelitian.

Pengujian berikutnya adalah uji asumsi klasik. Pengujian ini dilakukan dengan tujuan untuk memastikan hasil yang diperoleh memenuhi asumsi dasar di dalam analisis regresi. Hasil uji asumsi klasik yang dilakukan dalam penelitian ini adalah uji normalitas, uji multikoliniearitas, dan uji heteroskedastisitas. Uji normalitas bertujuan untuk mengetahui apakah residual dari model regresi yang dibuat berdistribusi normal atau tidak. Tabel 6 menunjukkan bahwa nilai Asymp.Sig (2-tailed) sebesar 0,200. Karena Asymp. Sig 
(p-value) 0,200 lebih besar daripada a $(0,05)$ maka dapat diinterpretasikan bahwa residual dari model telah berdistribusi normal.

Tabel 6. Hasil Uji Normalitas

\begin{tabular}{lc}
\hline & Unstandardized Residual \\
\hline $\mathrm{N}$ & 30 \\
Kolmogorov-Smirnov Z & 0,110 \\
Asymp.Sig.(2-tailed) & 0,200 \\
\hline
\end{tabular}

Sumber: Data Penelitian, 2018

Uji multikolinearitas bertujuan untuk menguji apakah di dalam model regresi ditemukan adanya korelasi antar variabel bebas. Berdasarkan Tabel 7 dapat dilihat bahwa nilai tolerance variabel bebas tidak ada yang kurang dari 10 persen $(0,1)$ dan seluruh variabel bebas memiliki nilai VIF kurang dari 10. Sehingga dapat disimpulkan bahwa pada data penelitian ini, tidak terjadi multikolinearitas antara variabel bebas dalam model regresi ini.

Tabel 7. Hasil Uji Multikolinearitas

\begin{tabular}{lrr}
\hline Variabel & Tolerance & VIF \\
\hline Penghargaan Finansial & 0,937 & 1,067 \\
Pelatihan Profesional & 0,932 & 1,073 \\
Lingkungan Kerja & 0,986 & 1,014 \\
\hline
\end{tabular}

Sumber: Data Penelitian, 2018

Uji heteroskedastisitas dilakukan untuk mengetahui apakah dalam model regresi terjadi ketidaksamaan varian. Hasil analisis pada Tabel 8 menunjukkan tidak ada pengaruh variabel bebas $\left(X_{1}, X_{2}\right.$ dan $\left.X_{3}\right)$ terhadap absolute residual (abs_res), baik secara serempak maupun parsial karena nilai Sig. lebih besar dari 0,05. Dengan demikian model yang dibuat tidak mengandung gejala heteroskedastisitas, sehingga layak digunakan untuk memprediksi.

Tabel 8. Hasil Uji Heteroskedastisitas

\begin{tabular}{|c|c|c|c|c|c|c|}
\hline & Model & $\begin{array}{r}\text { Uns } \\
\text { C }\end{array}$ & $\begin{array}{l}\text { dardized } \\
\text { icients }\end{array}$ & $\begin{array}{l}\text { Standardized } \\
\text { Coefficients }\end{array}$ & $t$ & Sig. \\
\hline & & $B$ & Std. Error & Beta & & \\
\hline & (Constant) & $-0,881$ & 2,966 & & $-0,297$ & 0,769 \\
\hline & $\begin{array}{l}\text { Penghargaan } \\
\text { Finansial }\end{array}$ & 0,070 & 0,137 & 0,102 & 0,512 & 0,613 \\
\hline 1 & $\begin{array}{l}\text { Pelatihan } \\
\text { Profesional }\end{array}$ & $-0,002$ & 0,086 & $-0,005$ & $-0,026$ & 0,979 \\
\hline & $\begin{array}{l}\text { Lingkungan } \\
\text { Kerja }\end{array}$ & 0,101 & 0,121 & 0,162 & 0,836 & 0,411 \\
\hline
\end{tabular}

Sumber: Data Penelitian, 2018

Analisis selanjutnya adalah analisis regresi linear berganda digunakan untuk mengetahui ketergantungan satu variabel terikat hanya pada satu variabel bebas dengan atau tanpa variabel moderator, serta untuk mengetahui ketergantungan satu variabel terikat pada variabel-variabel bebas. Uji ini dilakukan untuk mengetahui besarnya pengaruh penghargaan finansial $\left(X_{1}\right)$, pelatihan profesional $\left(X_{2}\right)$ dan lingkungan kerja $\left(X_{3}\right)$ pada minat mahasiswa PPAk memilih profesi sebagai akuntan publik (Y). Hasil uji regresi linear berganda dapat dilihat pada Tabel 9. 
Tabel 9. Hasil Analisis Regresi Linear Berganda

\begin{tabular}{|c|c|c|c|c|c|}
\hline \multirow{2}{*}{ Koefisien } & \multicolumn{2}{|c|}{$\begin{array}{c}\text { Unstandardized } \\
\text { Coefficients }\end{array}$} & \multirow{2}{*}{$\begin{array}{c}\begin{array}{c}\text { Standardized } \\
\text { Coefficients }\end{array} \\
\text { Beta }\end{array}$} & \multirow{2}{*}{$\mathrm{t}$} & \multirow{2}{*}{ Sig. } \\
\hline & $B$ & $\begin{array}{l}\text { Std. } \\
\text { Error }\end{array}$ & & & \\
\hline (Constant) & 10,750 & 4,908 & & 2,190 & 0,038 \\
\hline $\begin{array}{l}\text { Penghargaan } \\
\text { Finansial }\end{array}$ & 0,616 & 0,227 & 0,422 & 2,712 & 0,012 \\
\hline $\begin{array}{l}\text { Pelatihan } \\
\text { Profesional }\end{array}$ & 0,445 & 0,142 & 0,488 & 3,126 & 0,004 \\
\hline Lingkungan Kerja & 0,498 & 0,200 & 0,377 & 2,489 & 0,020 \\
\hline F hitung & $: 6,030$ & & & & \\
\hline Signifikansi F & $: 0,003$ & & & & \\
\hline R Square & $: 0,410$ & & & & \\
\hline Adjusted R Square & $: 0,342$ & & & & \\
\hline
\end{tabular}

Sumber: Data Penelitian, 2018

Berdasarkan hasil analisis yang disajikan pada Tabel 9, maka dapat disusun persamaan regresi sebagai berikut:

$$
\mathrm{Y}=10,750+0,616 \mathrm{X}_{1}+0,445 \mathrm{X}_{2}+0,498 \mathrm{X}_{3}
$$

Nilai konstanta sebesar 10,750 memiliki tanda positif yang artinya apabila penghargaan finansial $\left(X_{1}\right)$, pelatihan profesional $\left(X_{2}\right)$, lingkungan kerja $\left(X_{3}\right)$ sama dengan nol, maka nilai minat mahasiswa PPAk memilih profesi sebagai akuntan publik meningkat sebesar 10,750 satuan. Nilai koefisien regresi penghargaan finansial $\left(X_{1}\right)$ sebesar 0,616 , berarti menunjukan bahwa penghargaan finansial mempunyai hubungan positif terhadap minat mahasiswa PPAk memilih profesi sebagai akuntan publik di Universitas Udayana. Artinya semakin tinggi penghargaan finansial maka semakin tinggi minat mahasiswa PPAk memilih profesi sebagai akuntan publik di Universitas Udayana.

Nilai koefisien regresi pelatihan profesional $\left(X_{2}\right)$ sebesar 0,445 , berarti menunjukan bahwa pelatihan profesional mempunyai hubungan positif terhadap minat mahasiswa PPAk memilih profesi sebagai akuntan publik di Universitas Udayana. Artinya bahwa semakin tinggi pelatihan profesional maka semakin tinggi minat mahasiswa PPAk memilih profesi sebagai akuntan publik di Universitas Udayana. Nilai koefisien regresi lingungan kerja $\left(X_{2}\right)$ sebesar 0,498, berarti menunjukan bahwa lingkungan mempunyai hubungan positif terhadap minat mahasiswa PPAk memilih profesi sebagai akuntan publik di Universitas Udayana. Artinya bahwa semakin baik lingkungan kerja maka semakin tinggi minat mahasiswa PPAk memilih profesi sebagai akuntan publik di Universitas Udayana.

Sebelum dilakukan pengujian hipotesis, satu hal yang perlu diperhatikan adalah kelayakan model penelitian yang dilakukan dengan uji $F$ untuk mengetahui pengaruh variabel-variabel independen pada variabel dependen. Hasil analisis kelayakan model $\mathrm{F}$ dapat dilihat pada Tabel 9 menunjukkan bahwa nilai $F$ hitung sebesar 6,030 dengan nilai signifikansi uji $F$ yaitu sebesar 0,003 lebih kecil dari 0,05 yang berarti $\mathrm{H}_{1}$ diterima dan $\mathrm{H}_{0}$ ditolak. Hasil ini memberikan makna bahwa variabel penghargaan finansial, pelatihan profesional dan lingkungan pekerjaan dapat atau layak digunakan untuk memprediksi variabel pemilihan karir sebagai akuntan publik di Fakultas Ekonomi dan Bisnis 
Universitas Udayana. Hal ini menandakan model yang digunakan pada penelitian ini adalah layak.

Besarnya nilai Adjusted $R^{2}$ adalah sebesar 0,342. Hal ini menjelaskan bahwa 34,2 persen variasi besarnya pemilihan karir sebagai akuntan publik dapat dijelaskan oleh penghargaan finansial, pelatihan professional dan lingkungan pekerjaan. Sedangkan sisanya sebesar 65,8 persen dipengaruhi oleh variabelvariabel lain diluar model penelitian.

Berdasarkan hasil analisis pada Tabel 9 menunjukkan nilai t hitung pada variabel penghargaan finansial adalah sebesar 2,712 dengan tingkat signifikansi 0,012. Dengan menggunakan batas signifikansi 0,05 maka signifikansi tersebut dibawah taraf 5 persen yang berarti $\mathrm{H}_{0}$ ditolak dan $\mathrm{H}_{1}$ diterima. Hal ini menunjukkan bahwa penghargaan finansial berpengaruh positif pada pemilihan karir akuntan publik. Koefisien regresi variabel penghargaan $\left(X_{1}\right) 0,616$. Hal ini berarti bahwa apabila variabel penghargaan finansial $\left(X_{1}\right)$ meningkat satu satuan, maka akan mengakibatkan peningkatan pada pemilihan karir sebagai akuntan publik sebesar 0,616, dengan asumsi variabel bebas lainnya dianggap konstan.

Hasil analisis menunjukan koefisien regresi penghargaan finansial memiliki tanda positif. Hal ini menunjukkan bahwa semakin tinggi penghargaan finansial yang diharapkan oleh mahasiwa akuntansi menyebabkan minat mahasiswa PPAK memilih karir sebagai akuntan publik meningkat ataupun sebaliknya yaitu semakin rendah penghargaan finansial mahasiswa PPAk maka semakin rendah minat mahasiswa PPAk memilih karir sebagai akuntan publik. Hasil ini mendukung $\left(\mathrm{H}_{1}\right)$ yang menyatakan bahwa penghargaan finansial yang berpengaruh positif pada pemilihan karir sebagai akuntan publik.

Hasil penelitian ini sejalan dengan penelitian yang dilakukan oleh (Wijayanti, 2001) dan (Aprilyan, 2011) yang menunjukkan bahwa penghargaan finansial merupakan variabel yang di pertimbangkan dan berpengaruh dalam pemilihan karir akuntan publik. Mahasiswa akuntansi yang memilih karir menjadi akuntan publik lebih mengharapkan penghargaan finansial jangka panjang, gaji awal yang lebih tinggi dan kenaikan penghargaan finansial yang cepat. Berkarir di Kantor Akuntan Publik dapat menghasilkan pendapatan yang tinggi atau besar dan bervariasi dibandingkan dengan pendapatan yang diperoleh dari karir yang lain, karena semakin besar perusahaan atau klien yang menggunakan jasa akuntan publik, pendapatan yang diterima akan semakin tinggi.

Berdasarkan hasil analisis pada Tabel 9 nilai $\mathrm{t}$ hitung pada variabel pelatihan profesional adalah sebesar 3,126 dengan tingkat signifikansi 0,004. Dengan menggunakan batas signifikansi 0,05 maka signifikansi tersebut dibawah taraf 5 persen yang berarti $\mathrm{H}_{0}$ ditolak dan $\mathrm{H}_{2}$ diterima. Hal ini menunjukkan bahwa pelatihan profesional berpengaruh positif pada pemilihan karir sebagai akuntan publik. Koefisien regresi variabel pelatihan profesional $\left(\mathrm{X}_{2}\right)$ 0,445. Hal ini berarti bahwa apabila variabel pelatihan profesional $\left(X_{2}\right)$ meningkat satu satuan, maka akan mengakibatkan peningkatan pada pemilihan karir sebagai akuntan publik sebesar 0,445, dengan asumsi variabel bebas lainnya dianggap konstan.

Hasil analisis menunjukan koefisien regresi pelatihan profesional memiliki tanda positif. Hal ini menunjukan bahwa semakin sering pelatihan profesional 
yang diikuti menyebabkan minat mahasiswa PPAk memilih karir sebagai akuntan publik meningkat ataupun sebaliknya yaitu semakin rendah pelatihan profesional maka menyebabkan semakin rendah pula minat mahasiswa PPAk memilih karir sebagai akuntan publik. Hasil ini mendukung $\left(\mathrm{H}_{2}\right)$ yang menyatakan bahwa pelatihan profesional yang berpengaruh positif pada minat mahasisawa PPAk memilih karir sebagai akuntan publik.

Hasil penelitian ini juga konsisten dengan penelitian yang dilakukan oleh (Stolle, 1976) dalam (Alhadar, 2013) bahwa mahasiswa S1 akuntansi yang memilih karir menjadi akuntan public menganggap perlu untuk melakukan pelatihan kerja karena untuk menjadi seorang akuntan publik yang dapat melaksanakan pekerjaan audit dengan baik, tidak cukup hanya dengan bekal pendidikan formal semata tetapi juga harus ditunjang oleh pengalaman praktek di lapangan dengan jam kerja yang memadai.

Berdasarkan hasil analisis pada Tabel 9 nilai $t$ hitung pada variabel lingkungan pekerjaan adalah sebesar 2,489 dengan tingkat signifikansi 0,020. Dengan menggunakan batas signifikansi 0,05 maka signifikansi tersebut dibawah taraf 5 persen yang berarti $\mathrm{H}_{0}$ ditolak dan $\mathrm{H}_{3}$ diterima. Hal ini menunjukkan bahwa lingkungan pekerjaan berpengaruh positif pada pemilihan karir sebagai akuntan publik. Koefisien regresi variabel pelatihan profesional $\left(X_{3}\right) 0,498$. Hal ini berarti bahwa apabila variabel lingkungan pekerjaan $\left(X_{3}\right)$ meningkat satu satuan, maka akan mengakibatkan peningkatan pada pemilihan karir sebagai akuntan publik sebesar 0,498, dengan asumsi variabel bebas lainnya dianggap konstan.

Hasil analisis menunjukan koefisien regresi lingkungan pekerjaan memiliki tanda positif. Hal ini menunjukan bahwa semakin tinggi lingkungan pekerjaan yang didapat menyebabkan minat mahasiswa PPAk memilih karir sebagai akuntan publik meningkat ataupun sebaliknya yaitu semakin rendah lingkungan pekerjaan maka menyebabkan semakin rendah pula minat mahasiswa PPAk memilih karir sebagai akuntan publik. Hasil ini mendukung $\left(\mathrm{H}_{3}\right)$ yang menyatakan bahwa lingkungan pekerjaan yang berpengaruh positif pada minat mahasisawa PPAk memilih karir sebagai akuntan publik.

Hasil penelitian ini juga konsisten dengan penelitian yang dilakukan oleh (Yudhantoko, 2013) dan (Dwinanda, 2014) yang mana secara parsial lingkungan kerja berpengaruh terhadap pemilihan karir mahasiswa. Hasil ini membuktikan bahwa lingkungan kerja menjadi pilihan yang masih dipertimbangkan oleh mahasiswa pendidikan profesi akuntansi, dengan demikian hasil ini juga seakan memberi kesan bahwa karir sebagai akuntan professional merupakan karir yang tidak membosankan walaupun adanya kompetisi dan tekanan dalam bekerja yang tercermin dari jawaban respon atas angket yang peneliti sebar dan didukung dengan tingkat signifikan yang sangat tinggi.

\section{SIMPULAN}

Berdasarkan hasil analisis maka dapat ditarik kesimpulan yaitu penghargaan finansial berpengaruh positif dan pada pemilihan karir sebagai akuntan publik. Semakin tinggi penghargaan finansial mahasiswa tersebut maka akan semakin tinggi minat mahasiswa PPAK memilih karir sebagai akuntan publik. Pelatihan professional berpengaruh positif pada pemilihan karir sebagai akuntan publik. 
Semakin tinggi pelatihan professional mahasiswa tersebut maka akan semakin tinggi pula minat mahasiswa PPAk memilih karir sebagai akuntan publik. Lingkungan kerja berpengaruh positif pada pemilihan karir sebagai akuntan publik. Semakin baik lingkungan kerja mahasiswa tersebut maka akan semakin tinggi pula minat mahasiswa PPAk memilih karir sebagai akuntan publik.

\section{REFERENSI}

Aprilyan, Lara Absara. 2011. Faktor-Faktor Yang Mempengaruhi Mahasiswa Akuntansi Dalam Pemilihan Karir Menjadi Akuntan Publik. (Studi Empiris Pada Mahasiswa Akuntansi Undip Dan Mahasiswa Akuntansi Unika). Skripsi. Fakultas Ekonomi Universitas Diponegoro Semarang.

Alhadar, Mochammad Audi. 2013. Faktor-Faktor yang Mempengaruhi Pemilihan Karir Sebagai Akuntan Publik. (Studi Empiris Pada Mahasiswa Akuntansi dan PPAk Universitas Hasanuddin). Skripsi. Universitas Hasanudin Makasar.

Berry, Leonard and Parasuraman. 1997. Listening to the Customer: The Concept of A Service Quality Information System. Sloan Managenment Review. pp: 65-76.

Carl R. Philips and John L. Crain. 1996. Job Duties and Responsibilities in Public Accounting: Are Student Expectations Unrealistic? Journal of Education, 38(9): pp: 21-26.

Chairunisa, Fifi. 2014. Analisis Faktor-Faktor Yang Mempengaruhi Minat Mahasiswa Akuntansi Untuk Berkarir Sebagai Akuntan Publik. Jurnal Audit dan Akuntansi. 3(2).

Chan, Andy Setiawan. 2012. Analisis Faktor-faktor yang Mempengaruhi Pemilihan Karir Menjadi Akuntan Publik oleh Mahasiwa Jurusan Akuntansi. Jurnal Ilmiah Mahasiswa Akuntansi, 1(1): h: 53-58.

Dwinanda, Johan. 2014. Mempengaruhi Mahasiswa Akuntansi Dalam Pemilihan Karir Menjadi Auditor Pada Instansi Swasta Dan Pemerintah (Studi Empiris Pada Mahasiswa S1 Akuntansi Universitas Diponegoro). Skripsi. Universitas Diponegoro Semarang.

Felton, Sandra, Nola Buhr, and Margot Northey. 1994. Factors Influencing TheBusiness Student's Choice of a Career in Chartered Accountancy. Issues in Accounting Education. Spring. pp: 14-31.

Friedlan, J.M. 1997. The Effect of Different Teaching Approaches on Students Perceptions of the Skills Needed for Succes in Accounting Courses and by Practicing Accountants. Accounting Educations, 23(1).

Gibson, James, John M. Ivancevich, dan James H. Donnelly Jr. 1997. Organization: Behavior Structure Processes. Ninth Edition: McGraw-Hill, Inc

Greenberg, Jerald and Baron, Robert A. 2000. Behavior In Organization.Understanding and Managing the Human Side of Work, Upper SaddleRiver. New Jersey: Prentice Hall Inc.

Harrell, A., Caldwell, C. and Doty, E. 1985. Within-Person Expentancy Theory Predictions of Accounting Students' Motivation to Achieve Academic Succes. Accounting Review, 60: pp: 724-735.

Keputusan Mentri Pendidikan Nasional Republik Indonesia Nomor 179/U/2001. Tentang Penyelanggaraan Pendidikan Profesi Akuntansi Mentri Pendidikan 
Nasional.

Messmer, Max. 1997. Career Strategies for Accounting. Graduate, Student Suplement: Imastudent. Org. pp: 245-255.

Paolillo, J. G. P. Dan R.W. Estes. 1982. An Empirical Analysis of Career Choice Factors among Accountants, Attorneys, Engineers and Physicians. The Accounting Review, 57(4): pp: 785-793.

Rasmini, Ni Ketut. 2007. Faktor-Faktor Yang Berpengaruh Pada Keputusan Pemilihan Profesi Akuntan Publik Dan Nonakuntan Publik Pada Mahasiswa. Buletin Studi Ekonomi, 12(3): h:351-363.

Robbins, Stephen P. 2006. Perilaku Organisasi: Konsep, Kontroversi, Aplikasi. Alih Bahasa: Hadyana Pujaatmaka dan Benyamin Molan; Editor: Agus Widyantoro, Edisi 10. Jakarta: PT. Prenhallindo.

Sembiring, Simba M. 2009. Faktor-Faktor Yang Mempengaruhi Pemilihan Karir Menjadi Akuntan Publik Oleh Mahasiswa Departemen Akuntansi Fakultas Ekonomi USU Medan. Tesis. Sekolah Pasca Sarjana Universitas Sumatra Utara.

Suyono, Nanang Agus. 2014. Analisis Faktor - Faktor yang Mempengaruhi Pemilihan Karir Sebagai Akuntan Publik (Studi Empiris pada Mahasiswa Akuntansi UNSIQ). Jurnal Penelitian dan Pengabdian kepada Masyarakat UNSIQ, 1(2): 69-83.

Victor, Sg Tengker. 2007. Pengaruh Motivasi Karir Terhadap Minat Mahasiswa Akuntansi Untuk Mengikuti PPAk Studi Pada Jurusan Akuntansi FE Unsrat Manado. Riset Akuntansi. FE Unsrat Manado.

Wheeler, Anna, K. 2013. Determinan Pilihan Karir pada Mahasiswa Akuntansi (Studi Empiris pada Mahasiswa Akuntansi S1 Universitas Diponegoro) Jurnal Akuntansi. 2(3): h: 1-11.

Wheeler, K.G. 1983. Perception of Labour Market Variables by College Student in Bussiness, Education, and Psychology. Journal of Vocational Behavior. 22: pp: 1-11.

Wijayanti. 2001. Faktor-Faktor yang Mempengaruhi Pemilihan Karir Mahasiswa Akuntansi di Yogyakarta. Jurnal Riset Akuntansi Indonesia, 3: pp: 13-26.

Wildiana, Esi. 2014. Faktor-Faktor Yang Mempengaruhi Pemilihan Karir Profesi Akuntan Publik Bagi Mahasiswa Akuntansi. Jurnal Akuntansi. 1(1): h: 115.

Yudhantoko, Muhammad Bimo. 2013. Persepsi Mahasiswa Akuntansi Mengenai Minat dalam Pemilihan Karir sebagai Akuntan Perusahaan. Skripsi, Universitas Diponegoro, Semarang. 